\title{
LA FICCIÓN TELEVISIVA COMO RECURSO PARA LA DELIBERACIÓN SOBRE EL PASADO
}

Rosario Sánchez Vilela*

Recibido: Agosto 23, 2016 - Aceptado: Septiembre 26, 2016

RESUMEN: El artículo considera que el acceso al pasado a través de la ficción se constituye en un recurso para la deliberación sobre éste, su significación y lugar en la memoria colectiva. Se hace el abordaje de tres modalidades de relación entre memoria y ficción televisiva, con sus posibles derivaciones para la recepción.

El análisis de esas relaciones tiene como referencia las producciones iberoamericanas: Pablo Escobar: el patrón del mal, Cuéntame (memoria del trauma) y Graduados (memoria despolitizada).
Se considera, en sintonía con el pensamiento arendtiano, que solo a partir de un ejercicio de la imaginación es posible la comprensión así como la elaboración de opinión y juicio. Tres planos distintos, pero todos ellos necesarios para el compromiso ciudadano en el espacio público. La imaginación necesita recursos, y la ficción televisiva constituye una herramienta, ampliamente disponible, para ello.

Palabras clave: ficción televisiva, memoria colectiva, deliberación, Pablo Escobar, Cuéntame, Graduados.

*Doctora en Ciencia Política, Profesora Titular, Investigadora, Departamento de Comunicación de la Universidad Católica del Uruguay. Email: rsanchezvilela@gmail.com 


\section{THE TELEVISION FICTION AS A RESOURCE FOR DELIBERATION ON THE PAST}

SUMMARY: The article considers that access to the past through fiction constitutes a resource for deliberation about it, its significance and place in the collective memory. The approach of three modalities of relation between memory and television fiction, with its possible derivations for the reception.

The analysis of these relations is based on Ibero-American productions: Pablo Escobar: el patrón del mal,Cuentame (memory of trauma) and Graduados (depoliticized memory).
It is considered, in syntony with the Arendtian thought, that only from an exercise of the imagination is possible the understanding as well as the elaboration of opinion and judgment. Three different planes, but all of them necessary for the citizen commitment in the public space. Imagination needs resources, and television fiction is a widely available tool for this.

Keywords: television fiction, collective memory, deliberation, Pablo Escobar, Cuéntame, Graduados.

\section{A FICÇÃO DE TELEVISÃO COMO RECURSO PARA A DELIBERAÇÃO SOBRE O PASSADO}

RESUMO: O artigo considera que o acesso ao passado pela ficção em um recurso para a deliberação sobre este, sua significação e lugar na memória coletiva. Se faz a abordagem de três modalidades de relação entre memória e ficção de televisão, com suas possíveis derivações para a recepção.

A análise dessas relações tem como referência as produções ibero-americanas: Pablo Escobar: o padrão da injustiça, Cuentame ( memória do trauma) e Graduados (memória despolitizada). É considerado, em sintonia com o pensamento de Hannah Arendt que só a partir dum exercício da imaginação é possível a compreensão como também a elaboração de opinião e juízo. Três planos diferentes, mas tudo eles necessários para o compromisso cívico no espaço público. A imaginação precisa de recursos e a ficção de televisão constitui uma ferramenta, amplamente disponível, para isto.

Palavras chaves: ficção de televisão, memória coletiva, deliberação, Pablo Escobar, Cuentame, Graduados. 
a relación entre ficción televisiva y memoria [1] está inscripta en un problema que la engloba: el del vínculo entre ficción y realidad. A ello se suma la complejidad de nexos entre memoria e historia y los de ambas con la verdad. Carlo Ginzburg, en EI hilo y las huellas. Lo verdadero, lo falso, lo ficticio, recurre a una metáfora muy expresiva de estas relaciones: "La contigüidad entre ficción e historia hace pensar en esos cuadros de Magritte en que se representa, uno junto a otro, un paisaje y su reflejo en un espejo roto" [2].

La misma metáfora es utilizada por Gabriel García Márquez en Crónica de una muerte anunciada. Allí la refiere a la acción del narrador que vuelve al pueblo a "recomponer con tantas astillas dispersas el espejo roto de la memoria" con el propósito de reconstruir la historia de Santiago Nasar y Ángela Vicario, que es también la historia del pueblo, testigo-cómpliceresponsable de la muerte de Nasar.

En el esfuerzo, el narrador recompone la memoria, aunque no la verdad última que permanecerá oculta. En todo caso, ambos autores se refieren a la fragmentación, a la consiguiente pérdida de astillas, al esfuerzo de recuperación del pasado a la vez que a su inevitable deformación o modificación: el espejo roto no puede si no modificar la imagen. La fragmentación es inherente a la memoria en tanto ella es selección y olvido, pero también la historia trabaja sobre fragmentos buscando recuperar y comprender el pasado. $Y$ ambas suelen tener la pretensión de acceder a la verdad. La ecuación se hace más compleja al incorporar en esta relación a la ficción.

No es posible en este artículo, dar cuenta cabal de los diversos abordajes teóricos ni del entramado de discusiones que esta temática ha tenido [3]. No obstante, es relevante tener en cuenta la distinción aristotélica entre verdad y verosimilitud de la que se desprenden los límites del papel de la ficción en la configuración de la memoria social.

Aristóteles señala que "no es oficio del poeta el contar las cosas como sucedieron, sino como debieran o pudieran haber sucedido, probable o necesariamente; porque el historiador y el poeta no son diferentes por hablar en verso o en prosa (...) sino que la diversidad consiste en que aquel cuenta las cosas tales cuales sucedieron y este como era natural que sucediesen" [4]. Desde esta perspectiva, lo relevante para la ficción es la verosimilitud y ella no refiere a la verdad, sino a la apariencia: "contar fábulas con visos de verdad", en palabras de Aristóteles.
El problema se hace más complejo en aquellas ficciones que trabajan sobre el pasado histórico. Ellas se desarrollan en un doble registro: el de lo verosímil, pero también el de la relación con lo veraz, al menos en lo que refiere a la ocurrencia de los hechos. Esta exigencia de fidelidad a los hechos (a lo pasado real) en este tipo de ficciones es a la vez una pieza clave de su verosimilitud.

Desde estas condiciones y precisamente por ellas, la ficción ofrece una vivificación del pasado, permite al receptor la posibilidad de colocarse en las distintas subjetividades de los personajes, "ponerse en la piel de", incluso de aquellos cuyas acciones resultan condenables. En otras palabras: habilita y estimula la capacidad de imaginar. Ese recorrido por las diferentes subjetividades, forma parte del repertorio simbólico con el que se configuran las memorias, en interacción con otros relatos como los de la historiografía, los del periodismo, las memorias personales, los testimonios.

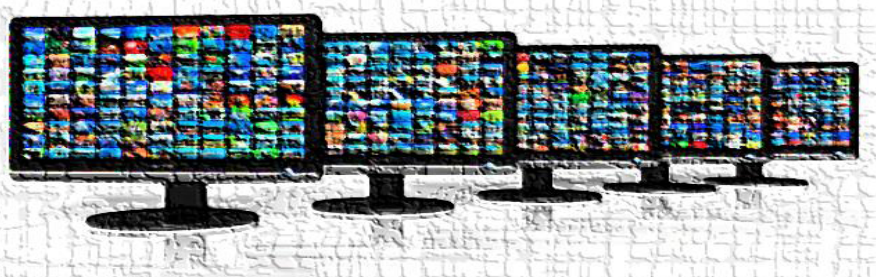

En este sentido es que se puede considerar a la ficción televisiva como parte de un proceso de construcción de las memorias colectivas en tanto ellas no son fijas e inamovibles, sino que como señala E. Jelin, "lo colectivo de las memorias es el entretejido de tradiciones y memorias individuales, en diálogo con otros, en estado de flujo constante" [5].

Las ficciones televisivas con su expansión comercial y amplitud de públicos forman parte de ese "flujo constante", de un tejido en permanente construcción. Ellas ponen a disposición un conjunto de imágenes y discursos que todos podemos ver. Más allá de que estemos de acuerdo o en desacuerdo con la interpretación del pasado que ofrezcan constituyen un territorio común sobre el que se trabaja y se discute la memoria. Porque la memoria se hace del recuerdo y el recordar, como señala Aristóteles en la siguiente cita, es una cualidad humana de la misma naturaleza que la deliberación: 
"Hemos explicado qué es la memoria o el recordar (...) y hemos explicado también a qué parte de nosotros pertenece: a saber, a la facultad sensitiva y primaria es decir, a aquella con que percibimos el tiempo (...) El recordar difiere de la memoria, no solamente en el aspecto del tiempo, sino también porque mientras que muchos otros animales participan de la memoria, se puede decir que ninguno de los animales conocidos, excepto el hombre, puede recordar. Por esta razón el recordar es como una especie de silogismo de inferencia; pues cuando un hombre recuerda, infiere o deduce que él antes ha visto, ha oído o ha experimentado algo de aquella clase, y el proceso de recordar es una especie de búsqueda. Este poder o capacidad solo puede corresponder por naturaleza a animales que posean la facultad de la deliberación: ya que también la deliberación es una especie de inferencia" [6].

\section{Metodología}

Este trabajo se ha propuesto indagar en las relaciones entre ficción televisiva y memoria social en el entendido de que aquella forma parte del flujo de componentes que, en interacción con otros, van configurando una visión del pasado. Para estudiar la complejidad conceptual y empírica que este fenómeno reviste se definió un eje temático, el pasado traumático, entre otras múltiples posibilidades del pasado. Otra decisión metodológica, ante la necesidad de acotar el objeto, consistió en definir un corte temporal y cultural: se limitó el campo a ficciones que refirieran o evocaran un contexto histórico ubicable en el pasado reciente, vale decir, a los últimos cuarenta años del siglo XX; ficciones iberoamericanas exhibidas en Uruguay en 2012. Por otra parte, se trató de abarcar ficciones que refirieran a pasados traumáticos diversos.

De la oferta de ficción televisiva de Uruguay se seleccionaron aquellas ficciones que presentaran algún trabajo sobre el pasado reciente. A ellas se les aplicó una matriz de observación en la que se registra la presencia del acontecimiento histórico y su relación con: la composición de la estructura de personajes; su lugar en la trama narrativa; el tipo de apelación a la memoria del espectador. Es este un tipo de análisis textual de corte cualitativo [7], centrado en la selección de tres casos, muestra significativa de la diversidad de posibilidades que la aplicación de la matriz puso de manifiesto.
2. Tres modos de relación de la ficción con la memoria del trauma.

Uno de los ejes nodales de la ficción que se ocupa del pasado es "el giro memorialista" que la literatura designa como la memoria del trauma, para referirse a todos aquellos relatos, ficcionales o no, vinculados a la vivencia del exterminio (con el Holocausto como referencia paradigmática), la guerra, la violencia extrema, las dictaduras, entre otros. Las ficciones que corresponden a esta clase, dan forma al trauma, lo modelan, de alguna manera lo domestican y hacen comprensible al integrarlo a un relato.

El cine tiene una larga trayectoria en ello y un lugar de reconocimiento fuera y dentro de los ámbitos académicos. Pero también las teleseries han representado la historia contemporánea y alguna de las experiencias traumáticas más recientes. Baste mencionar a modo de ejemplo Third Whatch, la primera serie que habló del 9 de setiembre de 2001 o Treme - considerada una teleficción de autor, expresión del diálogo de los últimos años entre cine y televisión [8] y el huracán Katrina.
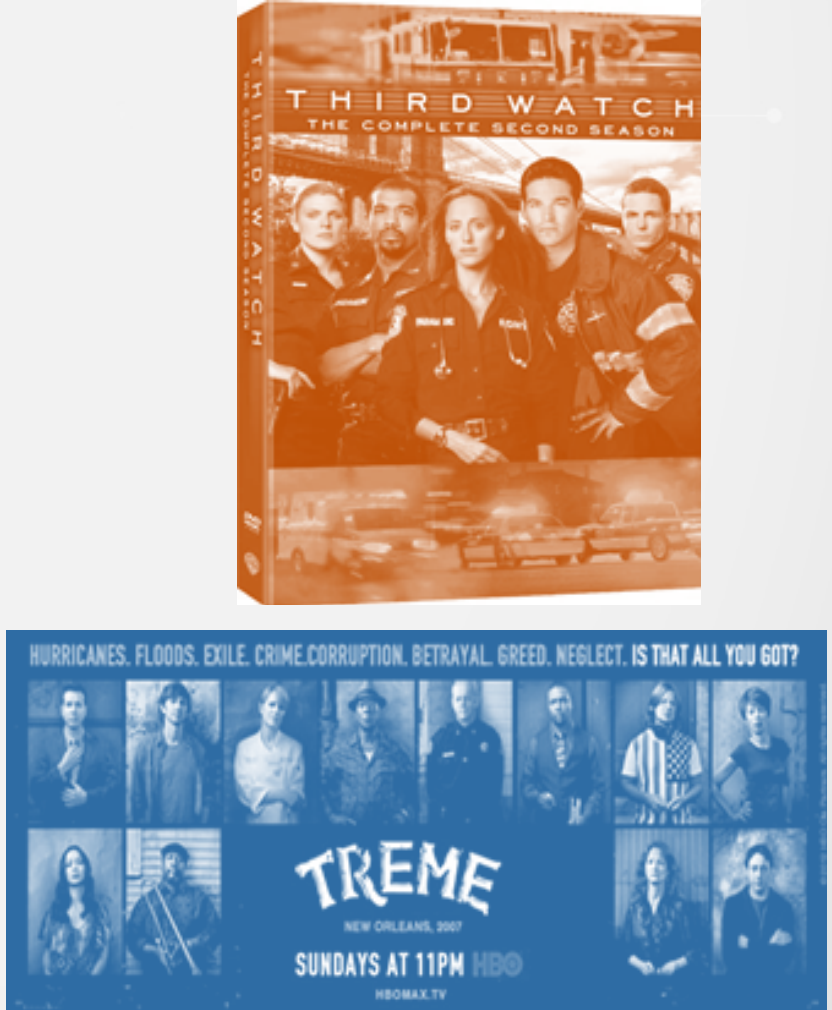

Las alusiones al trauma pueden ser más o menos explícitas, o al servicio de una interpretación que finalmente lo integre, como fortaleza, domesticado, a la identidad de una nación. Tal es el caso de Magnum en la que en los primeros tramos del primer capítulo el protagonista, después de desplegar sus habilidades físicas, se toma el brazo con gesto de dolor mientras 
el flash back evoca su pasaje por la guerra de Vietnam: el héroe forjado en la guerra, incluso ésta tan revulsiva para la sociedad estadounidense, finalmente contribuye a la templanza del heroismo integrado a una narrativa de la nacionalidad [9]. Más recientemente, Mad Men ofrece una mirada nostálgica sobre los años 60 que incluye el tiempo y las muertes de Kennedy y de Luther King [10]. El volumen de producción audiovisual de este tipo es inabarcable y necesariamente esta comunicación tendrá que acotar sus referencias para poder concentrarse.

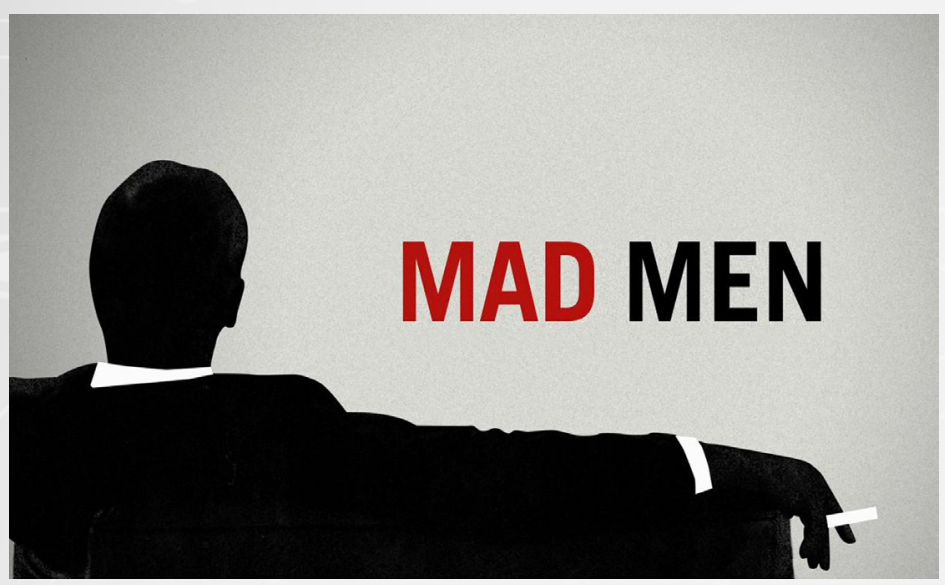

Sin pretender agotar el tema, me referiré a tres casos de ficción televisiva iberoamericana [11], que ilustran modos diversos de relación entre memoria ficción televisiva - recepción en contextos históricos en los que el trauma está presente. Las ficciones seleccionadas como referencia fueron exhibidas en Uruguay y plantearon maneras diferentes de relación con el pasado: una producción colombiana, Pablo Escobar: el patrón del mal, una serie española Cuéntame cómo pasó y la argentina Graduados.

Dos de las ficciones seleccionadas para este análisis, Pablo Escobar y Cuéntame, desenvuelven sus historias en el pasado y podrían ilustrar un tipo de relación: historias ficcionales o ficcionadas que recrean e interpretan la memoria del trauma, su objeto es el o los acontecimientos traumáticos (la violencia y el narcotráfico colombiano en una, la dictadura española en la otra). Sin embargo, cada una de ellas hace un trabajo distinto sobre el pasado y plantea una apelación a la memoria diferenciada.

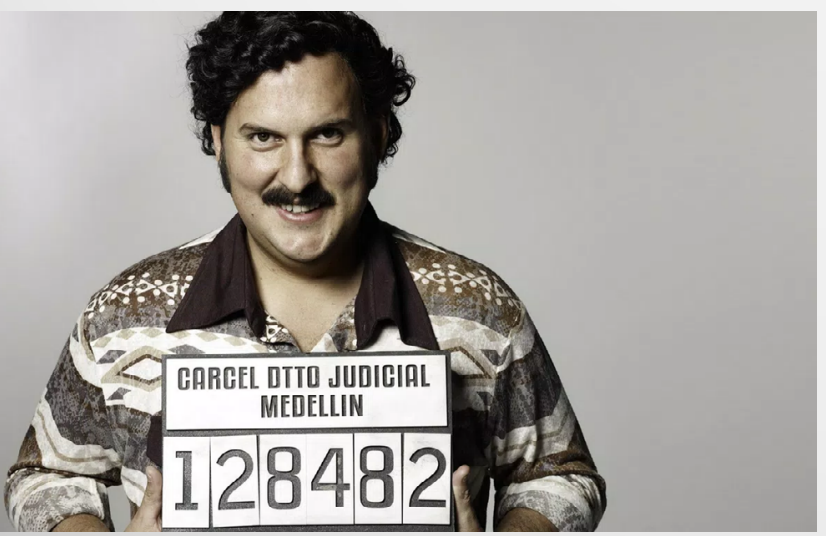

Pablo Escobar: el patrón del mal [12], recrea la historia del narcotraficante colombiano Pablo Emilio Escobar Gaviria en 113 capítulos. En esta ficción la apelación a la memoria se repite explícitamente al comienzo de cada capítulo: "Quien no conoce su historia está condenado a repetirla" es la frase que se lee sobre fondo negro. La afirmación revela aspectos centrales de la relación con los hechos traumáticos del pasado: por un lado "el pánico al olvido", experimentado desde el presente en el que quizás se observan síntomas de desmemoria y, por otro lado, la preocupación por el futuro, algo así como -tomando prestada la expresión de Giddens- una suerte de "colonización del futuro"[13] que, a partir del recuerdo, permita no volver a vivir el trauma. La canción que integra la apertura de cada capítulo se desarrolla en la misma línea semántica de tensión pasado-presente-futuro que se ha señalado:

"Contaré esta historia una y mil veces. Nunca más. Que no se borre de tu mente, en honor a nuestros muertos que cayeron vilmente." [14]

La ficción televisiva forma parte de los usos públicos de la historia y debe ser considerada expresión del presente y no solo del pasado. Es alguna inquietud del presente, alguna pregunta la que nos mueve hacia el pasado.

En Pablo Escobar, la ficción se inicia con el personaje Escobar momentos antes de su final. La concreción de su muerte se verá recién en el último capítulo, pero en los primeros tramos del primer capítulo se recorren hitos de violencia del cartel de Medellín a través de imágenes documentales, alternadas con la recreación ficcional, en un compacto audiovisual que concentra la historia al comienzo de la serie, para luego retomar el relato en un punto de inicio: 1959, con un Pablo Emilio Escobar niño. El centro de la narración es entonces aquí un personaje con existencia histórica.

En el caso de Cuéntame [15] los eventos de la historia española ocurridos durante los últimos años de la dictadura franquista y la transición hacia la democracia (la serie ubica su inicio en 1968) están presentes en los diálogos, en las imágenes que aparecen en los televisores de la serie, en fragmentos documentales, pero lo que constituye el centro del desarrollo narrativo es una familia de ficción, la familia Alcántara, su barrio, los personajes que a ella se vinculan. El acento está puesto entonces en los personajes de ficción y es en el transcurrir de su cotidianidad que se encarna la recreación del pasado. 
Hay aquí una apelación a memorias enlazadas: la que refiere a la peripecia nacional española y la que refiere a algunas transformaciones de las sociedades contemporáneas como la llegada de la televisión al hogar, la instalación del primer supermercado en un barrio y los cambios que ello produce en prácticas de consumo y relaciones sociales. Se trata de evocaciones que atraviesan distintos planos de la vida cotidiana: la escucha de la radio y su lugar en la rutina doméstica; la significación que tiene el acopio de alimento, la comida, para quien vivió la guerra y la posguerra; el sentido de autoridad del padre de familia y el lugar de las mujeres e hijos, significados en transformación y conflicto. La ficción funciona entonces como una "vivificación" del pasado porque es vivenciado por seres comunes $y$ corrientes como el espectador.

Es allí donde se enlazan en la serie las representaciones de las distintas memorias, públicas y privadas: por ejemplo, la memoria constituida por una sucesión de imágenes que evocan el anuncio de la muerte y el velatorio del dictador Francisco Franco (componente documental), con la memoria de cómo se vivió en los distintos hogares y por las diferentes generaciones ese momento histórico (componente ficcional). La instancia histórica traumática es evocada en esta ficción desde el hombre común y su cotidianidad con lo que se hace propicia la empatía y la identificación del receptor. No obstante, el acontecimiento histórico, el hecho está presente, explícito, documentado.

Un tercer tipo de relación entre ficción televisiva, memoria y recepción es el que puede ilustrar el caso de Graduados [16]. Esta ficción apunta a la memoria colectiva pero referida a un momento de la trayectoria personal que a los acontecimientos o personajes históricos: a través del grupo central de ocho personajes (los graduados) se apela a la evocación de la adolescencia, en permanente conexión con el presente adulto de los personajes porque allí se gestaron las relaciones amorosas que constituyen el motor narrativo de la ficción, así como los lazos de amistad y desencuentro que se desarrollan en el presente.
La década del ochenta es el pasado en el que se ubican esas evocaciones, pero a diferencia de las otras dos ficciones de las que nos ocupamos antes, aquí el contexto histórico solo es planteado con referencias musicales y con la participación en algunos capítulos, de cantantes emblemáticos del rock argentino de esos años (Charly García, Fabiana Cantilo o Fito Páez). Los personajes evocan momentos compartidos de su adolescencia: escenas del viaje a Bariloche, las clases de coro, la fiesta de graduación, por ejemplo, se insertan en la trama a través del flashback.

Se trata de un tipo de ficción en la que se produce una intervención sobre el pasado despolitizándolo. Los acontecimientos históricos de los años ochenta se omiten: no hay ninguna referencia a la dictadura, a la política argentina, ni a los procesos de transición hacia la democracia. Se trata de una narrativa en la que el trauma no tiene existencia. Los ochenta son una excusa para ubicar la ficción en relación a la edad de los personajes (y de los actores que los encarnan) en el presente, más que un tiempo en sí mismo relevante para la narración. No obstante, se produce una apelación a la memoria de la audiencia en el sentido de que cuenta con provocar el reconocimiento por parte del espectador de algunas prácticas adolescentes, de un conjunto de tópicos consensuados y de referencias musicales que el espectador puede identificar como parte de su biografía, pero a la vez inscripta en la experiencia colectiva.

\section{Ficciones televisiva que aportan a la constitución de un espacio público}

Otra aproximación a las relaciones entre ficción televisiva y memoria es aquella que toma en consideración al espacio público. Desde esta perspectiva la ficción televisiva contribuye a la constitución de un espacio público ensanchado en la que las memorias nacionales se interpenetran. Las ficciones como Pablo Escobar: el patrón del mal o la española Cuéntame [17], en las que se representan acontecimientos históricos específicos de un país, pero que se exhiben en muchos otros, forman parte de un repertorio simbólico e interpretativo con el que se conforman memorias colectivas que trascienden las fronteras del país del origen.

Imágenes ficcionales, fragmentos documentales, vivencia privada del acontecimiento público, (como la muerte del director del periódico El Espectador de Colombia en Pablo Escobar: el patrón del mal, o el atentado en España a Carrero Blanco y la muerte de Franco, en Cuéntame, circulan en las ficciones 
traspasando fronteras en lo que Jean-Marc Ferry [18] define como "el espacio público ensanchado": un espacio fundamentalmente definido por el marco mediático en el que los espacios públicos de los diferentes países se interpenetran, pero también sus pasados y los debates que ellos provocan en el presente.

Si bien los géneros informativos y documentales son los que más intensamente generan esa expansión del espacio público, las ficciones no cumplen un papel menor en este sentido. Así, la teledramaturgia y el cine sobre el Holocausto, la Segunda Guerra Mundial o los atentados a las Torres Gemelas, entre otros hitos de la historia, pasan a integrar un universo de recursos compartidos de la memoria. Esa circulación de representaciones del pasado con sus correspondientes ejercicios de memoria (recuerdo y olvido, selección y omisión) permiten la construcción imaginaria de los "otros" que se muestran en la ficción, al mismo tiempo que el reconocimiento de un "nosotros" con proximidades y distancias respecto a aquellos.

En esa dirección Ferry señala que "el espacio público se puede entender como un medio privilegiado para la formación de una identidad colectiva mediante la apropiación de la historia (...) una sociedad halla un acceso significativo para ella misma o para otras en la (...) memoria de los pueblos. Actualiza su pasado; es más, se familiariza con el de las demás $\mathrm{y}$, por lo tanto, puede aprender a reconocer las identidades alejadas prima facie de la suya propia. De ello resulta cierta profundidad de la comunicación social, profundidad que apenas podría concebirse sin ese espacio público históricamente extendido y literalmente enriquecido" [19].

\section{Consideraciones finales}

Un tipo de relación de memoria y ficción es la que se produce respecto a un pasado traumático. Se han subrayado aquí dos caminos habitualmente recorridos por la ficción televisiva: uno, que coloca el eje en la reconstrucción histórica de protagonistas reales y acontecimientos, el otro, en el que la recreación ficcional pone el énfasis en lo cotidiano en un marco histórico-epocal preciso. En la primera modalidad de relación con el pasado, se habilita al receptor a un doble juego: recorrer la experiencia vicaria, a la vez que se mantiene una distancia reflexiva respecto al personaje histórico.

En la segunda modalidad de relación con el pasado, la opresión y ausencia de libertad se experimenta y descubre desde la óptica de alguien que no ha pensado en ello, como Antonio Alcántara. Este tipo de relación promueve la identificación del receptor de una manera más empática. En cambio cuando el centro está puesto en los protagonistas históricos hay una épica, un aura de heroísmo y/o de excepcionalidad que provoca distanciamiento.

No obstante, lo que constituye a mi entender el aspecto más relevante es que, en todo caso, la ficción televisiva que apela a la memoria y recreación del pasado histórico, hace un uso público de la historia y constituye una herramienta para la imaginación personal y colectiva.

El acceso al pasado a través de la ficción constituye así un recurso para la deliberación sobre ese pasado, sobre su significación y su lugar en la memoria colectiva. El papel de la imaginación como recurso imprescindible para la elaboración del juicio y para la fortaleza de la esfera pública, ha sido particularmente señalado por Arendt:

\footnotetext{
"Solo la imaginación nos permite ver las cosas en la perspectiva correcta, nos da fuerza suficiente para poner a cierta distancia lo que está demasiado próximo, de modo que podamos ver y comprender sin parcialidad y sin prejuicio; solo ella nos permite superar el abismo de la lejanía hasta que vemos y comprendemos lo que está demasiado lejos de nosotros como si fuera asunto propio. Distanciar algunas cosas y saltar el abismo que nos separa de otras formas parte del diálogo de la comprensión, para cuyos fines la experiencia directa constituye un contacto demasiado íntimo y el mero conocimiento erige barreras artificiales. Sin este tipo de imaginación, que en realidad es comprensión, jamás podríamos orientarnos en el mundo. Es la única brújula interna que tenemos. Sólo somos contemporáneos de lo que está al alcance de nuestra comprensión" [19].
}

Se ha dicho aquí que la ficción permite una vivificación del pasado. Se ha dicho también que ella guarda una compleja relación con lo real. Se trata de una simulación, apariencia de verdad, en términos aritotélicos, verosimilitud que en las ficciones históricas o epocales exige cierta fidelidad con el pasado real, aún mateniendo el artificio. Allí radica su pontecialidad para promover la capacidad imaginativa de las audiencias.

Es en el sentido que indica Arendt que la ficción televisiva contribuye a la deliberación sobre el pasado. La deliberación, entre otros rasgos, exige la capacidad de colocarse en la perspectiva del otro, abandonar o dejar en suspenso las propias 
convicciones, para comprender el punto de vista ajeno y sopesar lo que puede aportar a la comprensión del asunto que se tiene entre manos. Vivir la historia de otro, ponerse su piel: eso es lo que permite la ficción de una manera más libre que otras prácticas comunicativas.

La ficción televisiva en general cumple este papel en el espacio público. Ella constituye un escenario de mostración de lo distante y diferente que puede contribuir, para bien y para mal, a la elaboración del juicio y la opinión. Es un ámbito en el que el otro, con sus problemas y conflictos, se hace visible en múltiples representaciones: proporciona instrumentos para imaginar al otro, pero sobre todo constituye un género privilegiado para ponerse en el lugar del otro. En otras palabras, ella ofrece una articulación de distancia y proximidad desde donde comprender una determinada problemática anclada en experiencias concretas de seres humanos.

Los personajes de la ficción habilitan a diferentes formas del reconocimiento, pero al mismo tiempo el espectador sabe que es un artificio, lo que implica cierto distanciamiento. En ese sentido la ficción permitiría "poner a distancia lo próximo" a la vez que "superar el abismo de la lejanía" para tomarlo "como si fuera asunto propio". La ficción puede ofrecer diversidad de puntos de vista de lugares desde donde se experimenta una situación, un conflicto un problema $y$, tomando prestada la expresión de Silverstone, "darle cabida en la imaginación a todos los otros posibles" [20].

En suma, solo a partir de un ejercicio de la imaginación es posible la comprensión así como la elaboración de opinión y juicio. Tres planos distintos, pero todos ellos necesarios para el compromiso ciudadano en el espacio público. La imaginación necesita recursos, y la ficción televisiva constituye una herramienta, ampliamente disponible, para ello.

\section{Bibliografía}

Aristóteles, Poética, cap IV, Espasa Calpe, Buenos Aires, 1948.

Carrión, J. Teleshakespeare. Las series en serio, Tintable, México, 2015.

Eherhaus, Peter en "Narrativas culturales y motivo terapéutico: la contención política de los veteranos de Vietnam". En Mumby, D. (comp.) Narrativa y control social. Perspectivas críticas, Amorrortu, Buenos Aires, 1997.
Ferry, Jean-Marc, El nuevo espacio público, Gedisa, Barcelona, 1998.

Fiske, John. "Brithish Studies and Television", en Channels o discourse. Television and Contemporary Criticism.Robert Allen (comp.) University of North Carolina Press, 1987.

Ginzburg, Carlo, El hilo y las huellas. Lo verdadero, lo falso, lo ficticio, Fondo de Cultura Económica, Argentina, 2010.

González Camaño, Oscar, “¡Han matado a Kenedy! Hijos de puta!". El contexto histórico en Mad Men. En AAVV Mad Men o la frágil belleza de los sueños en Madison Avenue. España. Ed. Errata naturae, 2015.

Guiddens, Anthony, Modernidad e identidad del yo, Península, Barcelona, 1997.

Huyssen, Andreas, En busca del futuro perdido, Fondo de Cultura Económica, México, 2002.

Jelin, Elizabeth, Las políticas de la memoria, Siglo XXI, Buenos Aires, 2002.

Larsen, P., Análisis textual del contenido de ficción de los medios de comunicación. En: Jensen, K. B. y Jankowski (eds.), Metodologías cualitativas de investigación en comunicación de masas, Bosch, Barcelona, 1993.

Mumby, Dennis, Narrativa y control social. Perspectivas críticas. Amorrortu, Buenos Aires, 1997.

Ricoeur, Paul, La memoria, la historia y el olvido, Fondo de Cultura Económica, Buenos Aires, 2004.

Rilla, José (2008) "Historias en segundo grado. Pierre Nora y los lugares de la memoria" http://www. trilce.com.uy/pierre-nora-en-les-lieux-de-memoire. html (consultado 18 de setiembre 2016).

Rilla, José, La actualidad del pasado. Los usos de la historia en la política de partidos del Uruguay (18421872), Ed. Sudamericana, Montevideo, 2008.

Silverstone, R., La moral de los medios de comunicación. Sobre el nacimiento de la polis de los medios, Amorrortu, Buenos Aires, 2007.

Vassallo de Lopes, Ma. Immacolata; Orozco, Guillermo (coord.) Memoria Social y Ficción Televisiva en Países Iberoamericanos,Ed Sulina, Porto Alegre, 2013. 
and Contemporary Criticism.Robert Allen (comp.)

[1] Es Maurice Halwachs quien introduce el concepto de memoria social o memoria colectiva para referirse a un modo de configuración de la memoria que condiciona la memoria individual. La tradición francesa continúa el desarrollo conceptual en dos direcciones: una representada fundamentalmente por Pierre Nora, vinculada al estudio de las identidades nacionales, la otra que sostiene la coexistencia de diversas memorias en una sociedad. Los medios de comunicación, el cine, la televisión constituyen componentes centrales en la configuración de la memoria colectiva, como lo ha señalado Andreas Huyssen. Halbwachs, Maurice, Los marcos sociales de la memoria, Barcelona, Anthropos, 2004; Halbwachs, Maurice, La memoria colectiva, Zaragoza, Prensas Universitarias de Zaragoza, 2004;Nora, Les Lieux de mémoire I La République, París, Gallimard, 1984 ; Huyssen, Andreas, En busca del futuro perdido, México, Fondo de Cultura Económica, 2002.

[2] Guinzburg, C., El hilo y las huellas. Lo verdadero, lo falso, lo ficticio, Fondo de Cultura Económica, Argentina, 2010, 20.

[3] Una revisión intensa de la teoría producida al respecto puede verse en Rilla, J.: Usos públicos de la historia, En: La actualidad del pasado. Los usos de la historia en la política de partidos del Uruguay (1842-1872), Ed. Sudamericana, Montevideo, 2008.

[4] Aristóteles, Poética, cap IV, Espasa Calpe, Buenos Aires, 1948.

[5] Jelin, Elizabeth Las políticas de la memoria, Siglo XXI, Buenos Aires, 2002, 22.

[6] Aristóteles, Del sentido de lo sensible y De la memoria y el recuerdo, Aguilar 1962 pag. 88, 9697, citado en Rilla, J., La actualidad del pasado. Los usos de la historia en la política de partidos del Uruguay (1842-1872),Ed. Sudamericana, colección Debate, Montevideo, 2008, 52-53.

[7] Larsen, P., Análisis textual del contenido de ficción de los medios de comunicación. En: Jensen, K. B. y Jankowski (eds.), Metodologías cualitativas de investigación en comunicación de masas, Bosch, Barcelona, 1993.

[8] Carrión, J. Teleshakespeare. Las series en serio, Tintable, México, 2015, 183.

[9] Ver el análisis que prone Fiske, J. "Brithish Studies and Television", En Channels o discourse. Television
University of North Carolina Press, 1987, 293-295.

Otro enfoque de las narrativas sobre la guerra de Vietnam, la represión de la memoria de esa guerra perdida y su recuperación en relato de contención es el que plantea Peter Eherhaus en "Narrativas culturales y motivo terapéutico: la contención política de los veteranos de Vietnam". En Mumby, D. (comp.) Narrativa y control social. Perspectivas críticas, Amorrortu, Buenos Aires, 1997, 107-131.

[10] González Camaño, O., "¡Han matado a Kennedy! ¡Hijos de puta! El contexto histórico”. En Crisóstomo, R; Ros, E.: Mad Men o la frágil belleza de los sueños en Madison Avenue, Errata Nature, España, 2015, 84-85.

[11]Una primera aproximación al tema fue presentada en el marco del trabajo del Observatorio Iberoamericano de Ficción Televisiva (OBITEL) que dedicó el Anuario 2013, Vassallo de Lopes, Ma. Immacolata; Orozco, Guillermo (coord.) Memoria Social y Ficción Televisiva en Países Iberoamericanos, Ed Sulina, Porto Alegre, 2013.

[12]Pablo Escobar el patrón del mal. Producción: Caracol Televisión. Dirección: Carlos Moreno. Guionistas: Juan Camilo Ferrand. Elenco: Andrés Parra-Angie Cepeda- Nicolás Montero- Cecilia Navia- Aldemar Correa- Germán Quintero- Helena Mallarino- Christian Tappan- Alejandro MartinezErnesto Benjumea- Carlos Mariño- Marcela GallegoJuancho Arango- Diana Hoyos- Vicky HernándezDiana Neira. En Uruguay fue emitida en 2012 por Montecarlo. Alcanzó un rating de 7,1 y un share de 12.

[13] Guiddens, A. Modernidad e identidad del yo, Ed. Península, Barcelona, 1997.

[14]La canción es La última bala de Yuri Buenaventura.

[15]Cuéntame, serie de Televisión Española. Creada por Miguel Ángel Bernardeu. Producción: Grupo Ganga. Elenco: Imanol Arias, Ana Duato, María Galiana, Juan Echanove. Emitida por TNU en 2012 llega a medir: rating: $1,9 \%$. share: $3 \%$.

[16] Graduados, Producción: Underground Contenidos y Endemol._Dirección: Miguel ColomPablo Ambrosini- Javier Pérez. Guionistas: Ernesto Korovsky- Silvina Frejdkes- Alejandro Quesada. Elenco: Nancy Dupláa- Daniel Hendler- Luciano Cáceres-Julieta Ortega- Isabel Macedo. Emitida por Montecarlo. Rating: $11,1 \%$. Share: $17 \%$. 
[17] Ferry, Jean-Marc, El nuevo espacio público, Gedisa, Barcelona 1998.

[18] Ídem, pág. 20.

[19] Arendt, H. (1994, 323) citada por Silverstone, R. La moral de los medios de comunicación. Sobre el nacimiento de la polis de los medios., Amorrortu, Buenos Aires, 2010, 77.

[20] Silverstone, R., La moral de los medios de comunicación. Sobre el nacimiento de la polis de los medios, Amorrortu, Buenos Aires, 2007, 78.

\section{Para citar este artículo:}

Sánchez, V. Rosario (2016). La ficción televisiva como recurso para el debate del pasado. Revista Luciérnaga / Comunicación, Año 8, N16. Facultad de Comunicación Audiovisual- Politécnico Colombiano Jaime Isaza Cadavid- PCJIC \& Facultad de Ciencias de la Comunicación Universidad Autónoma de San Luis Potosí- UASLP. México. Págs. 38-47.

\section{DOI. 10.33571/revistaluciemaga.v8n16a4}

Link: http://www.politecnicojic.edu.co/images/downloads/ publicaciones/revista-luciernaga/luciernaga-14/ 